\title{
Macromycological research in Finland
}

\section{PAAVO KALLIO}

KALLIO, P. 1978: Macromycological research in Finland. - Karstenia 18 (suppl.).

The history of mycological research in Finland began with William Nylander who collected the first specimens for the mushroom herbarium (H) in the middle of the 19th century. P.A. Karsten (1834-1917) was, however, the person who has contributed the most significantly to the knowledge of Finnish mycoflora. After him there followed a rather inactive period in the study of macrofungi, although some material was increased in number, especially from the Helsinki area.

Renewed activity started in the middle of the 20th century. The Finnish Mycological Society was founded in 1948 and its periodical KARSTENIA is a good indicator of the mycological research carried out since then. The teaching of mycology in universities was started in the $1960^{\prime} \mathrm{s}$. Some mapping of the distribution of fungi has been possible and the main distributional zones are discussed. The maps, it is true, still indicate to a great part the history of collecting and the locations of the centres of mycological research. part the history of collecting and the locations of the centres of mycological research.
The present extensive and varied activity in mycology is reflected in the wide group of persons co-operating in mycological studies in Finland.

P. Kallio, Department of Botany, University of Turku, SF-20500 Turku 50, Finland. 